\title{
Efektivitas Model Problem Based Learning Ditinjau dari Kemampuan Pemecahan Masalah Matematika
}

\section{The Effectiveness of Problem Based Learning Model in Terms of The Ability to Solve Math Problems}

\author{
Padrul Jana $^{1}$, Endah Supiati ${ }^{2}$ \\ ${ }^{1,2}$ Pendidikan Matematika, Keguruan dan Ilmu Pendidikan, Universitas PGRI Yogyakarta, Jln. \\ PGRI II Sonopakis Lor No. 240 Yogyakarta, 55182 \\ ${ }^{1 *}$ Korespondensi Penulis. E-mail: padrul.jana@upy.ac.id, Telp: +6285295579152
}

\begin{abstract}
Abstrak
Penelitian ini bertujuan untuk mengetahui efektivitas model Problem Based Learning dengan pembanding model pembelajaran langsung ditinjau dari kemampuan pemecahan masalah matematika. Penelitian ini dilakukan di SMA Negeri 1 Pajangan dengan mengambil sampel siswa kelas X MIPA 2 sebagai kelas eksperimen dan kelas X MIPA 1 sebagai kelas kontrol. Jenis penelitian ini menggunakan Quasi Eksperiment (eksperimen semu) dengan desain penelitian The Nonequivalent Posttest-Only Control Group Design. Analisis data yang dilakukan yaitu analisis data uji coba soal posttest kemampuan pemecahan masalah matematika, analisis data hasil observasi keterlaksanaan pembelajaran dengan model Problem Based Learning dan model pembelajaran langsung, dan analisis data hasil posttest kemampuan pemecahan masalah matematika yang meliputi uji normalitas dengan menggunakan uji Kolmogorov Smirnov serta uji hipotesis dengan menggunakan uji $\mathrm{T}$ dengan taraf signifikansi $\alpha=0,05$. Hasil penelitian menunjukkan bahwa kedua kelas dalam keadaan awal yang setimbang. Berdasarkan uji normalitas nilai posttest kemampuan pemecahan masalah matematika pada kelas eksperimen diperoleh nilai sig. 0,057 $>\alpha$ dan pada kelas kontrol diperoleh nilai sig. 0,200 $>\alpha$, sehingga kedua kelas berdistribusi normal. Berdasarkan uji $\mathrm{T}$ nilai posttest kemampuan pemecahan masalah matematika pada kedua kelas diperoleh $t_{\text {hitung }}=2,15>t_{\text {tabel }}=1,99773$, sehingga dapat disimpulkan bahwa model Problem Based Learning lebih efektiv daripada model pembelajaran langsung ditinjau dari kemampuan pemecahan masalah matematika siswa kelas X MIPA SMA Negeri 1 Pajangan Bantul.
\end{abstract}

Keyword: Kemampuan Pemecahan Masalah Matematika, Model Pembelajaran Langsung, Model Problem Based Learning .

\begin{abstract}
This research aims to know the effectiveness of Problem Based Learning model with a comparison of direct learning model in terms of mathematical problem-solving ability. The research was conducted in SMA Negeri 1 Pajangan Bantul by taking the sample of students on X MIPA 2 as experiment class and X MIPA 1 as control class. This type of research uses quasi-experimental with design research The Nonequivalent Posttest-Only Control Group Design. Data analysis which was conducted named analysis of test data on the posttest problem of mathematical problem solving ability, analysis of learning results of learning implementation data with Problem Based Learning models and direct learning models, and posttest data analysis of mathematical problem solving abilities including normality tests using the Kolmogorov Smirnov test and hypothesis testing using the T-test with a significance level of $\alpha=0.05$. The results of the study indicate that the two classes are in a balanced initial state. Based on the normality test of the posttest value the
\end{abstract}


ability to solve mathematical problems in the experimental class obtained the sig value 0.057> $\alpha$ and in the control class the sig value is obtained 0.200> $\alpha$, so those two classes are normally distributed. Based on the T-test the posttest value of mathematical problem-solving skills in both classes was obtained t_hitung $=2,15>t$ tabel $=1,99773$, and finally, it can be concluded that the Problem Based Learning model is more effective than the direct learning model in terms of mathematical problem-solving abilities of class students on X MIPA SMA Negeri 1 Pajangan Bantul.

Keyword: Ability to solve math problems, Direct learning model, Problem Based Learning model.

\section{PENDAHULUAN}

Matematika merupakan salah satu ilmu pengetahuan dasar yang berperan dalam meningkatkan kemampuan generasi penerus bangsa melalui pengembangan pola pikir dan daya nalar (Jana, 2018; Jana \& Sugiyarta, 2018). Pelajaran matematika diberikan pada semua jenjang pendidikan mulai dari SD, SMP, SMA hingga Perguruan Tinggi pada beberapa cabang ilmu tertentu. Selain itu, matematika juga banyak diterapkan dalam kegiatan sehari-hari, seperti perdagangan, pembangunan, pertanian, dan lain-lain. Hal ini menunjukkan matematika memiliki peranan penting dalam kehidupan.

Salah satu tujuan pembelajaran matematika adalah siswa mampu memecahkan masalah yang meliputi kemampuan memahami masalah, merancang model matematika, menyelesaikan model, dan menafsirkan solusi yang diperoleh (Effendi, 2012). Matematika merupakan bidang studi yang berguna untuk menyelesaikan berbagai masalah dalam kehidupan sehari-hari, terutama yang berhubungan dengan hitung menghitung dan memerlukan suatu keterampilan serta kemampuan untuk memecahkannya.

Berdasarkan hasil observasi, SMA Negeri 1 Pajangan Bantul merupakan salah satu sekolah yang sudah menerapkan kurikulum 2013. Akan tetapi, dalam proses pembelajaran masih sering menggunakan model pembelajaran langsung, dimana model pembelajaran langsung ini dirasa belum banyak melibatkan siswa secara aktif.

Model pembelajaran sangat berperan penting dalam kegiatan belajar mengajar agar tercapai tujuan belajar yang optimal. Salah satu model pembelajaran yang dapat digunakan dalam pembelajaran matematika adalah model Problem Based Learning. Model ini sebagai salah satu model pembelajaran yang memiliki ciri khas yaitu selalu dimulai dan berpusat pada suatu masalah (Fatimah, 2012). Selain itu, model ini juga dapat mendorong siswa untuk berpikir memecahkan suatu masalah, memberikan pengalaman bagi siswa untuk lebih aktif dalam pembelajaran, dan membantu siswa dalam mengkonstruksikan pengetahuan serta mengaitkan pembelajaran yang ada di sekolah dalam kehidupan nyata (Sulaeman \& Astriyani, 2016; Riski Nur Istiqomah Dinnullah,2018).

Berdasarkan hasil wawancara dengan salah satu guru mata pelajaran matematika di SMA Negeri 1 Pajangan Bantul, ketika siswa diberikan soal tentang pemecahan masalah, belum banyak siswa yang dapat menyelesaikan soal tersebut dengan benar. Selain itu juga dibutuhkan waktu yang cukup lama untuk menyelesaikan soal tersebut. Hal ini menunjukkan bahwa kemampuan siswa dalam memecahkan masalah matematika masih belum maksimal. Model Problem Based Learning merupakan model pembelajaran yang melibatkan siswa dalam memecahkan masalah nyata. Model Problem Based Learning juga menjadi wadah bagi siswa untuk dapat mengembangkan cara berpikir kritis dan keterampilan berpikir yang lebih tinggi (Gunantara, Suarjana, \& Riastin, 2014), dimana siswa diberi kesempatan untuk mengembangkan kemampuannya dalam berpikir, sedangkan guru hanya berperan sebagai fasilitator. Harapannya dengan model Problem Based Learning ini siswa mampu menyelesaikan permasalahan yang dihadapi berdasarkan pengalamannya (Hariyati, Mardiyana, \& Usodo, 2013).

Model Pembelajaran langsung merupakan cara yang paling efektif untuk mengajarkan konsep dan keterampilan-keterampilan yang eksplisit kepada siswa yang berprestasi rendah sekalipun (Ekasari \& Sahidu, 2016). Model ini dirancang khusus untuk menunjang proses belajar siswa yang berkaitan dengan pengetahuan deklaratif dan pengetahuan prosedural yang terstruktur 
dengan baik dan dapat diajarkan secara bertahap selangkah demi selangkah untuk mempertahankan fokus pencapaian akademik (Sakti, Mega, Puspasari, Eko, \& Risdianto, 2012).

Tabel 1. Langkah- langkah pembelajaran berbasis masalah

\begin{tabular}{|c|c|}
\hline Indikator & Tingkah Laku Guru \\
\hline Orientasi siswa pada masalah & $\begin{array}{l}\text { Menjelaskan tujuan pembelajaran, menjelaskan logistik } \\
\text { yang diperlukan, dan memotivasi siswa terlibat pada } \\
\text { aktivitas pemecahan masalah }\end{array}$ \\
\hline $\begin{array}{l}\text { Mengorganisasi siswa untuk } \\
\text { belajar }\end{array}$ & $\begin{array}{l}\text { Membantu siswa mendefinisikan dan mengorganisasikan } \\
\text { tugas belajar yang berhubungan dengan masalah tersebut }\end{array}$ \\
\hline $\begin{array}{l}\text { Membimbing pengalaman } \\
\text { individual/ kelompok }\end{array}$ & $\begin{array}{l}\text { Mendorong siswa untuk mengumpulkan informasi yang } \\
\text { sesuai, melaksanakan eksperimen untuk mendapatkan } \\
\text { penjelasan dan pemecahan masalah }\end{array}$ \\
\hline $\begin{array}{l}\text { Mengembangkan dan menyajikan } \\
\text { hasil karya }\end{array}$ & $\begin{array}{l}\text { Membantu siswa dalam merencanakan dan menyiapkan } \\
\text { karya yang sesuai seperti laporan, dan membantu mereka } \\
\text { untuk berbagai tugas dengan temannya }\end{array}$ \\
\hline $\begin{array}{l}\text { Menganalisis dan mengevaluasi } \\
\text { proses pemecahan masalah }\end{array}$ & $\begin{array}{l}\text { Membantu siswa untuk melakukan refleksi atau evaluasi } \\
\text { terhadap penyelidikan mereka dan proses yang mereka } \\
\text { gunakan. }\end{array}$ \\
\hline
\end{tabular}

Sumber: (Rusman, 2016)

Tabel 2. Sintaks model pembelajaran langsung

\begin{tabular}{|c|c|}
\hline Fase-fase & Perilaku Guru \\
\hline $\begin{array}{l}\text { Menyampaikan tujuan } \quad \text { dan } \\
\text { mempersiapkan siswa }\end{array}$ & $\begin{array}{l}\text { Menjelaskan tujuan, materi prasyarat, memotivasi } \\
\text { siswa dan mempersiapkan siswa }\end{array}$ \\
\hline $\begin{array}{l}\text { Mendemonstrasikan pengetahuan dan } \\
\text { keterampilan }\end{array}$ & $\begin{array}{l}\text { Mendemonstrasikan keterampilan atau menyajikan } \\
\text { informasi tahap demi tahap }\end{array}$ \\
\hline Membimbing pelatihan & Guru memberikan latihan terbimbing \\
\hline $\begin{array}{l}\text { Mengecek pemahaman dan memberikan } \\
\text { umpan balik }\end{array}$ & $\begin{array}{l}\text { Mengecek kemampuan siswa apakah siswa telah } \\
\text { berhasil melakukan tugas dengan baik dan } \\
\text { memberikan umpan balik }\end{array}$ \\
\hline $\begin{array}{l}\text { Memberikan latihan dan penerapan } \\
\text { konsep }\end{array}$ & $\begin{array}{l}\text { Mempersiapkan latihan untuk siswa dengan } \\
\text { menerapkan konsep yang telah dipelajari pada } \\
\text { kehidupan sehari-hari }\end{array}$ \\
\hline
\end{tabular}

Sumber: (Jauhar, 2011)

Kemampuan pemecahan masalah merupakan aspek penting dalam proses belajar mengajar matematika baik sekarang maupun di masa depan (Rahmani \& Widyasari, 2018). Kemampuan pemecahan masalah juga merupakan kesanggupan siswa dalam menggabungkan berbagai konsep, aturan, serta prinsip yang telah mereka pelajari sebelumnya untuk menyelesaikan suatu persoalan yang diberikan (Amperawan, Pujawan, \& Suarsana, 2018).

Indikator kemampuan penyelesaian masalah matematis, yaitu: (1) mengidentifikasi unsurunsur yang diketahui, ditanyakan, dan kecukupan unsur yang diperlukan, (2) merumuskan masalah matematis atau menyusun model matematis, (3) menerapkan strategi untuk menyelesaikan masalah, (4) menjelaskan atau menginterprestasikan hasil penyelesaian masalah (Lestari, K. E. \& Yudhanegara, 2015).

\section{METODE}

Jenis penelitian ini adalah penelitian eksperimen. Desain penelitian yang digunakan dalam penelitian ini adalah Quasi Experimental Design dengan bentuk The Nonequivalent Posttest-Only Control Group Design. Populasi dalam penelitian ini adalah seluruh kelas X MIPA. Sampel yang diambil adalah kelas X MIPA 2 sebagai kelas eksperimen dengan model Problem Based Learning dan kelas X MIPA 1 sebagai kelas kontrol dengan model pembelajaran langsung. Penelitian ini dilaksanakan pada bulan April-Mei 2018 pada semester 2 tahun pelajaran 2017/2018 di SMA 
Negeri 1 Pajangan yang beralamat di Kedung, Guwosari, Pajangan, Bantul, Daerah Istimewa Yogyakarta. Instrumen yang digunakan dalam penelitian ini meliputi soal tes dan lembar observasi. Analisis data yang dilakukan yaitu analisis data uji coba soal posttest kemampuan pemecahan masalah matematika, analisis data hasil observasi keterlaksanaan pembelajaran dengan model Problem Based Learning dan model pembelajaran langsung, dan analisis data hasil posttest kemampuan pemecahan masalah matematika yang meliputi uji normalitas dengan menggunakan uji Kolmogorov Smirnov serta uji hipotesis dengan menggunakan uji $\mathrm{T}$ dengan taraf signifikansi $\alpha=$ 0,05 .

\section{HASIL DAN PEMBAHASAN}

Berdasarkan hasil observasi, keterlaksanaan pembelajaran dengan model Problem Based Learning dan pembelajaran langsung berjalan dengan sangat baik. Melalui kegiatan guru dan kegiatan siswa, keterlaksanaan pembelajaran dengan model Problem Based Learning pada pertemuan pertama sebesar 95\% dan pada pertemuan kedua sebesar 92,5\%, sedangkan keterlaksanaan pembelajaran dengan model pembelajaran langsung pada pertemuan pertama sebesar $100 \%$ dan pada pertemuan kedua sebesar $88,24 \%$.

Tabel 3. Analisis Tes Kemampuan Pemecahan Masalah Matematika

\begin{tabular}{llllll}
\hline No & KE & KK & No & KE & KK \\
\hline 1 & 100 & 72,92 & 18 & 100 & 100 \\
2 & 95,83 & 87,50 & 19 & 97,92 & 91,67 \\
3 & 79,17 & 81,25 & 20 & 85,42 & 87,50 \\
4 & 93,75 & 95,83 & 21 & 97,92 & 95,83 \\
5 & 93,75 & 81,25 & 22 & 85,42 & 75,00 \\
6 & 100 & 68,75 & 23 & 91,67 & 93,75 \\
7 & 100 & 83,33 & 24 & 91,67 & 68,75 \\
8 & 77,08 & 100 & 25 & 85,42 & 85,42 \\
9 & 95,83 & 100 & 26 & 77,08 & 79,17 \\
10 & 89,58 & 81,25 & 27 & 77,08 & 97,92 \\
11 & 75,00 & 95,83 & 28 & 93,75 & 87,50 \\
12 & 93,75 & 93,75 & 29 & 89,58 & 85,42 \\
13 & 100 & 91,67 & 30 & 100 & 72,92 \\
14 & 89,58 & 72,92 & 31 & 100 & 87,50 \\
15 & 91,67 & 95,83 & 32 & 93,75 & 79,17 \\
16 & 85,42 & 100 & 33 & 100 & 97,92 \\
17 & 97,92 & 83,33 & & & 87,00 \\
Rata-rata & & & 91,67 & Sangat baik \\
Kriteria & & & Sangat baik & . \\
\hline
\end{tabular}

Berdasarkan analisis kemampuan pemecahan masalah matematika siswa, diperoleh nilai rata-rata pada kelas eksperimen (KE) sebesar 91,67 dan pada kelas kontrol (KK) sebesar 87,00 dengan kriteria sangat baik.

Tabel 4. Uji Normalitas Kelas Eksperimen

\begin{tabular}{lccc}
\hline \multicolumn{4}{l}{ Tests of Normality } \\
\hline \multirow{3}{*}{ Kolmogorov-Smirnov } \\
\cline { 2 - 4 } PBL & Statistic & Df & Sig. \\
\cline { 2 - 4 } &, 150 & 33 &, 057 \\
\hline
\end{tabular}

Tabel 5. Uji Normalitas Kelas Kontrol

\begin{tabular}{llll}
\hline \multicolumn{4}{l}{ Tests of Normality } \\
\hline & \multicolumn{3}{c}{ Kolmogorov-Smirnov } \\
\cline { 2 - 4 } LSG & Statistic & Df & Sig. \\
\cline { 2 - 4 } &, 121 & 33 &, $200^{*}$ \\
\hline
\end{tabular}


Berdasarkan perhitungan pada uji hipotesis pertama, diperoleh $t_{\text {hitung }}=15,82>t_{\text {tabel }}=$ 2,03693. Sehingga model Problem Based Learning efektif ditinjau dari kemampuan pemecahan masalah matematika siswa kelas X MIPA SMA Negeri 1 Pajangan Bantul. Berdasarkan perhitungan pada uji hipotesis kedua, diperoleh $t_{\text {hitung }}=10,06>t_{\text {tabel }}=2,03693$. Sehingga model pembelajaran langsung efektif ditinjau dari kemampuan pemecahan masalah matematika siswa kelas X MIPA SMA Negeri 1 Pajangan Bantul. Berdasarkan perhitungan pada uji hipotesis ketiga, diperoleh $t_{\text {hitung }}=2,15>t_{\text {tabel }}=1$,99773. Sehingga model Problem Based Learning lebih efektif daripada model pembelajaran langsung ditinjau dari kemampuan pemecahan masalah matematika siswa kelas X MIPA SMA Negeri 1 Pajangan Bantul.

Model Problem Based Learning lebih efektif daripada model pembelajaran langsung, karena model Problem Based Learning sangat sesuai dan cocok untuk kemampuan pemecahan masalah matematika. Berdasarkan kajian teori, model Problem Based Learning mampu mengarahkan siswa untuk memahami masalah dan melibatkan siswa secara aktif dalam memecahkan masalah matematika. Hal ini sesuai dengan hasil pengamatan proses pembelajaran di kelas eksperimen menggunakan model Problem Based Learning. Melalui model Problem Based Learning, siswa menjadi lebih termotivasi, sehingga rasa ingin tahu mereka meningkat. Selain itu, model Problem Based Learning juga menjadi wadah bagi siswa untuk dapat mengembangkan kemampuan berfikirnya secara optimal dalam memecahkan suatu masalah matematika.

\section{SIMPULAN}

Berdasarkan penelitian yang telah dilaksanakan, hasil uji normalitas menunjukkan bahwa kelas eksperimen dengan model Problem Based Learning dan kelas kontrol dengan model pembelajaran langsung berdistribusi normal. Hasil pengujian hipotesis pada taraf signifikansi 5\% melalui perhitungan nilai posttest kelas eksperimen dan kelas kontrol diperoleh bahwa t_hitung= 2,15>t_tabel=1,99773 (uji signifikan). Sehingga dapat disimpulkan bahwa model Problem Based Learning lebih efektif daripada model pembelajaran langsung ditinjau dari kemampuan pemecahan masalah matematika siswa kelas X MIPA SMA Negeri 1 Pajangan Bantul.

\section{DAFTAR PUSTAKA}

Amperawan, I. W., Pujawan, I. G. N., \& Suarsana, I. M. (2018). Komparasi kemampuan pemecahan masalah matematika antara pmr dan pbm pada materi geometri smp kelas vii. Fibonacci, 4(1), 47-60. https://doi.org/10.24853/fbc.4.1.47-60

Effendi, L. A. (2012). Pembelajaran matematika dengan metode penemuan terbimbing untuk meningkatkan kemampuan representasi dan pemecahan masalah matematis siswa SMP. Jurnal Penelitian Pendidikan, 13(2), 1-10.

Ekasari, R. R., \& Sahidu, H. (2016). Pengaruh Model Pembelajaran Langsung Berbantuan Media Laboratorium Terhadap Kreatifitas Fisika Siswa SMA. Jurnal Pendidikan Fisika Dan Teknologi, II(3), 106-110.

Fatimah, F. (2012). Kemampuan komunikasi matematis dan pemecahan masalah melalui problem based-learning. Jurnal Penelitian Dan Evaluasi Pendidikan Tahun, 16(1), 249-259. https://doi.org/https://doi.org/10.21831/pep.v16i1.1116

Gunantara, G., Suarjana, M., \& Riastin, P. N. (2014). Penerapan Model Pembelajaran Problem Based Learning Untuk Meningkatkan Kemampuan Pemecahan Masalah Matematika Siswa Kelas V. Jurnal Mimbar PGSD Universitas Pendidikan Ganesha, 2(1).

Hariyati, E., Mardiyana, \& Usodo, B. (2013). Efektivitas Model Pembelajaran Kooperatif Tipe Team Assisted Individualization ( Tai ) Dan Problem Based Learn I Ng ( Pbl ) Pada Prestasi Belajar Matematika Ditinjau Dari Multiple Intelligences Siswa SMP Kabupaten Lampung Timur Dengan model Menurut kooper. Jurnal Elektronik Pembelajaran Matematika, 1(7), $721-731$. 
Jana, P. (2018). Penguatan Kemampuan Matematika Dasar Siswa SMA Melalui Kegiatan Matrikulasi. MATAPPA: Jurnal Pengabdian Kepada Masyarakat, 1(1), 1-4. https://doi.org/http://dx.doi.org/10.31100/matappa.v1i1.80

Jana, P., \& Sugiyarta, A. W. (2018). Active Learning Berbantuan Flashcard Untuk Meningkatkan Hasil Belajar Matematika Pada Materi Vektor. Aksioma Jurnal Pendidikan Matematika FKIP Univ. Muhammadiyah Metro, 7(3), 492-502. https://doi.org/http://dx.doi.org/10.24127/ajpm.v7i3.1538

Jauhar, M. (2011). Implementasi PAIKEM dari Behavioristik sampai Kontruktivistik. Jakarta: Prestasi Pustaka.

Lestari, K. E., \& Yudhanegara, M. R. (2015). Penelitian Pendidikan Matematika. Bandung: PT Refika Aditama.

Nuryadi, N. (2019). Pengembangan Media Matematika Mobile Learning Berbasis Android ditinjau dari Kemampuan Pemecahan Masalah. Jurnal pendidikan surya edukasi (JPSE), 5(1), 1-13.

Rahmani, W., \& Widyasari, N. (2018). Meningkatkan Kemampuan Pemecahan Masalah Matematis Siswa Melalui Media Tangram. Fibonacci, 4(1), 17-24. https://doi.org/10.24853/fbc.4.1.1723

Riski Nur Istiqomah Dinnullah, (2018). Perbedaan Model Problem Based Learning Dan Discovery-Inquiry Ditinjau Dari Hasil Belajar Matematika Siswa. Jurnal Mercumatika : Jurnal Penelitian Matematika dan Pendidikan Matematika FKIP Universitas Mercu Buana Yogyakarta,3(1),01-08 https://dx.doi.org/10.26486/jm.v3i1.654

Rusman. (2016). Model-model Pembelajaran Mengembangkan Profesionalisme Guru Edisi Kedua. Jakarta: Rajawali Press.

Sakti, I., Mega, Y., Puspasari, Eko, \& Risdianto. (2012). Pengaruh model pembelajaran langsung (direct instruction) melalui media animasi berbasis macromedia flash terhadap minat belajar dan pemahaman konsep fisika siswa di sma plus negeri 7 kota bengkulu. Exacta, 10(1), 110 .

Sulaeman, E., \& Astriyani, A. (2016). Upaya Meningkatkan Kemampuan Pemecahan Masalah Matematika Siswa Melalui Strategi Problem Based Learning Pada Kelas VIII-C SMP Muhammadiyah 29 Sawangan Depok. Fibonacci, 2(1), 31-43. https://doi.org/https://doi.org/10.24853/fbc.2.1.31-43 